\title{
Obtention of new ornamental leaf variants of giant reed (Arundo donax L.) originated from somatic embryogenesis and their photosynthetic parameters
}

\author{
Antal, G. ${ }^{1}$, Fári, M. G. ${ }^{2}$, Domokos-Szabolcsy, É. ${ }^{2}$ \\ ${ }^{1}$ University of Debrecen, Faculty of Economics and Business, Institute of Sectoral Economics and Methodology, \\ 138. Böszörményi str., Debrecen, H-4032, Hungary \\ ${ }^{2}$ University of Debrecen, Faculty of the Agricultural and Food Sciences and Environment Management, \\ 138. Böszörményi str., Debrecen, H-4032, Hungary \\ Author for corresponding: antal.gabriella@econ.unideb.hu
}

\begin{abstract}
Summary: Giant reed (Arundo donax L.) is a perennial rhizomatous herbaceous plant, it has been widespread all over the world by human activities. It is a 2-8 meter high, polyploid, sterile species (not produce viable seeds), it can be propagated only by vegetative methods (rhizomes, stem cuttings, in vitro biotechnological methods). It has considered promising dedicated energy crop thanks to high biomass production (20-40 dry tons per hectare depending on microclimate), adaptability of different kind of soils and environment and low energy input required for its cultivation. It has been utilized for energetic purposes, biogas/bioethanol production, cellulose/paper production and ornamental purposes. The objectives of the present study were to determine morphological properties of new ornamental giant reed leaf variants originated from somatic embryogenesis and to evaluate their photosynthetic pigment content and photosynthetic activities. The most typical changes was the appearance of different colour (white, yellow, light green) longitudinal stripes on leaves (also on petiole and on leaf blade). It was significant differences $(\mathrm{p}<0.05)$ between green and leaf variants in case of photosynthetic pigments content and photosynthetic activity (Fv/Fm value). There was no detectable chlorophyll $a$ or $b$ content in the white bands of leaves and albino shoots. Total chlorophyll content of the white striped leaf variety was more than twice than the light green leaves. Photosynthetic activity and content of photosynthetic pigments also confirm and determine the morphological characteristics and growth habit of leaf variants.
\end{abstract}

Antal, G., Fári, M. G., Domokos-Szabolcsy, É. (2018): Obtention of new ornamental leaf variants of giant reed (Arundo donax L.) originated from somatic embryogenesis and their photosynthetic parameters. International Journal of Horticultural Science 24(1-2): 18-24. https://doi.org/10.31421/IJHS/24/1-2./1542

Key words: striped leaf variants of ornamental giant reed, dedicated biomass plant,

photosynthetic pigment content, photosynthetic activity

\section{Introduction}

Giant reed (Arundo donax L.) belongs to Poaceae family, has been known as perennial rhizomatous herbaceous ornamental plants, but thousands of years ago has already been utilized as woodwind musical instruments, construction materials or energy resources (Perdue, 1958). Giant reed is a 28 meters high, polyploidy, sterile species, not produce viable seeds, it has been originated from East Asia and spread by human activities (Pilu et al., 2012). Natural populations of giant reed can be found from tropical to continental conditions. Intact and not cultivated, 50-years-old giant reed populations exist over the world (Shatalov \& Pereira, 2002). In Europe, it has been present widespread in the Mediterranean basin and can be found population in the Balaton basin, in Hungary.

It is considered as invasive weed especially in coastal regions in warmer climate areas. Aggressive spread of giant reed (invasiveness) has been reported in numerous literature from USA (Bell, 1997; Quinn et al., 2015), from Europe (Pilu et al., 2012; Maceda-Veiga et al., 2016) and from Australia (Ferdinands et al., 2011; Invasive Plant Risk Assessment, 2016).

In spite of all these, giant reed has been considered one of the most promising dedicated energy species, it has been utilized in production of bioethanol, cellulose/paper, biogas, heat, electrical energy, or chemical basic compounds etc. (ElBassam, 1996; Christou et al., 2001; Lewandowski et al., 2003; Angelini et al., 2005; Mantineo et al., 2009; Pilu et al., 2012). Its important role thanks to high biomass production (20-40 dry tons per hectare depending on microclimate and rainfall), adaptability of different kind of soils and environment, content of lignocellulose and low energy input required for its cultivation. It has been known as ornamental species, but used as reeds in woodwind instruments, fishing rod, stakes for plants, roof thatching etc. (Corno et al., 2014).

The industrial utilization of giant reed has been limited the unsatisfactory or even lack of large-scale, programmable, inexpensive propagation method and restricted breeding opportunity. It does not produced viable seed, so it can be propagated vegetative ways by rhizomes or stem cuttings (Ceotto \& Di Candilo, 2010; Pilu et al., 2013) and by in vitro biotechnology methods (Bacher et al., 2001; Takahashi et al., 2010; Gubišová et al., 2016).

There are different striped giant reed variegations as ornamental purposes in international trade (Figure 1). Arundo donax var. versicolor (Mill.) Kunth. has described in 1768, it is a white striped leaf variegation also known as 'Variegata'. The maximum height of this variety is $4-5$ meters, the culms are 
less hard, rigid and produce more variegated shoots and leaves than typical giant reed (Perdue, 1958) (Figure 1a). 'Variegata superba' (Figure $1 b$ ) is similar to striped variety, but its shoots are higher and its leaves are wider. There are leaf variegations having a low height ( 1 meter) and their culms diameter is smaller than other typical giant reed (Figure $1 c$ ). The leaves of 'Golden Chain' variety are yellowish green (Figure 1d).

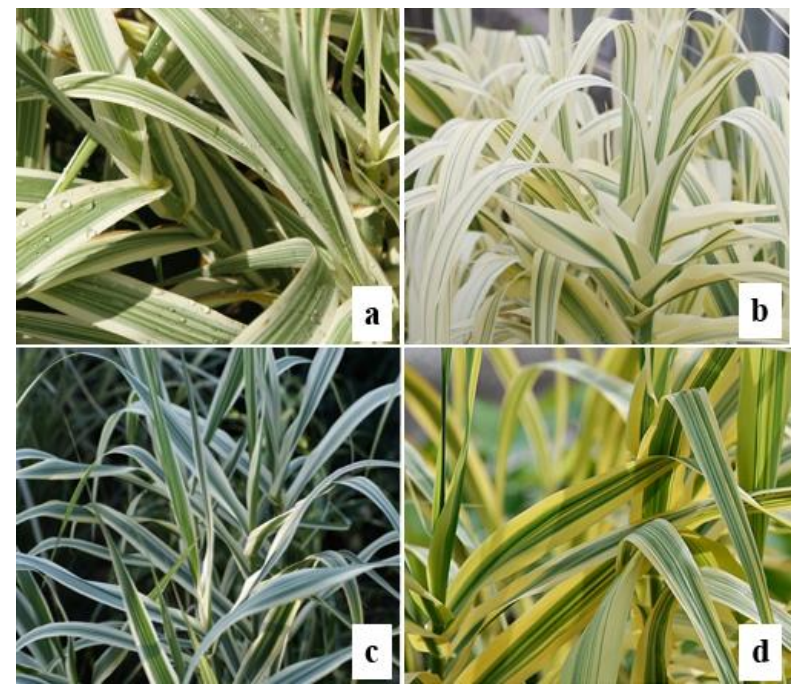

Figure 1. Varieties of striped giant reed in international trade

Source: A) Arundo donax var. versicolor (Big Plant Nursery). B) 'Variegata superba' (Future Gardens). C) 'Variegata' (Palm Exotics). D) 'Golden Chain' (Water Plants Italy).

Genetic diversity has low among populations of giant reed originated from different territories due to the asexual reproduction (Mariani et al., 2010; Hardion et al., 2012). The chromosome number of giant reed is diverse $(110,108,84$ etc.) depending on countries in which the plant has grown and author's studies (Corno et al., 2014). Based on experiments of Hardion (2013) the chromosome number of a leaf variegation is similar to green species, and the genetic diversity is very low between typical giant reed and Arundo donax var. versicolor. Some studies has reported morphological differences between giant reed species originated from different areas, these socalled ecotypes could adapt different climate conditions (Pompeiano et al., 2015). The leaves of 'Macrophylla' are erect, bluish green and wide (about $9 \mathrm{~cm}$ ), but 'Longicaulis' variety has longer and pendulous leaves than other giant reed species (El-Bassam \& Dalianis, 2010).

We have been conducting morphological, physiological and genetic researches with different giant reed ecotypes and leaf varieties. The objective of present paper is a comparative analysis of giant reed leaf variants with wild type, green plants considering morphological characterization and photosynthetic parameters.

\section{Materials and methods}

\section{Plant material and field experiment}

In vitro propagation of giant reed using somatic embryogenesis were elaborated at University of Debrecen, Department of Plant Biotechnology based on methods of Márton \& Czakó (2002a, b, c, 2007a, b). During the propagation process, white/albino plants has been appeared (Figure $2 a$ ). These in vitro shoots were disappeared or dead after isolation (lack of viable green shoots). Within the framework of the University of South Carolina (USA) and the University of Debrecen joint research program, has been developed in vitro propagation techniques of giant reed. As results of cooperation, the large-scale production of virus-free somatic seedlings originating from somatic embryo (even from flowering stem cells), can contribute the establishment of industrial biomass plantations in Hungary and in several other countries around the world.

In 2012 we could select and produce 11 different giant reed leaf variants in greenhouse from 500,000 acclimatized somatic plantlets (Antal et al., 2013). We could reach more giant reed variants using Antal et al. (2014) advanced propagation method based on embryogenesis, which were planted to Experiment Garden of Future Biomass Crops at University of Debrecen (Figure 2b).

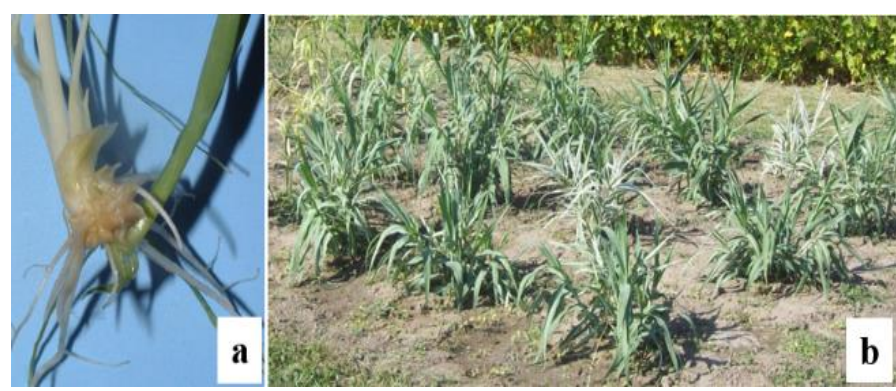

Figure 2. Varieties of striped giant reed derived by somatic embryogenesis at University of Debrecen (Hungary - July 2014)

Source: photos by Gabriella Antal

Varieties were cultivated in clay loamy, slightly alkaline $(7.93 \mathrm{pH} \pm 0.025)$ chernozem soil with relatively high humus content $(3.14 \% \pm 0.407)$ and significant $\mathrm{CaCO}_{3}$ content $(4.67 \%$ $\pm 0.00)$. The nitrogen content of the soil was very low, but its phosphorus and potassium content were high (Alshaal et al., 2013; 2014). Between 2012-2016, in Demonstration Garden, Debrecen was characterized by the following average meteorological data: annual mean temperature was $11.6^{\circ} \mathrm{C}$, average maximum temperature was $36.2^{\circ} \mathrm{C}$, average minimum temperature was $14.4^{\circ} \mathrm{C}$, mean sunshine hours was 2300 hours/year. Average precipitation was about 430-530 mm/year (Hungarian Central Statistical Office, 2016).

\section{Measurement of morphological parameters}

The main morphological properties of different leaf variants (number of shoots, length of shoots, growth habits) were compared with giant reed varieties and species which have already described in the literature. Based on colour difference and position of banding (stripes) in the leaves we classified the variants in 6 types. The stability of new variants were monitored during 4 cultivation years without irrigation.

\section{Photosynthetic pigment determination}

Photosynthetic pigment content and ratio were determined in three colour variants (light green or yellowish, white/albino and white-green striped) compared to wild type (green) giant reed. Leaf disc was cut and extracted by N'N dimethylformamide overnight at $4 \mathrm{C}^{\circ}$ in dark. We measured the content and proportion of different photosynthetic pigments of variants per unit of leaf area by Porra et al. (1989) method with spectrophotometer (Ultrospec 2100 Pro UV/Visible, 
Amersham Biosciences, USA) at 664, 646 and $480 \mathrm{~nm}$. Chlorophyll $a$ (chl $a$ ), chlorophyll $b$ (chl $b$ ), carotinoids (car), chl $a+b$, chl $a / b$ and car/chl ratio were calculated.

\section{Photosynthetic electron transport and fast chlorophyll a fluorescence transient}

The chl $a$ fluorescence of dark adapted intact leaf variegated plants was measured by indirect fluorescence measurement with chlorophyll fluorimeter $(650 \mathrm{~nm}$ peak wavelength, $300 \mu \mathrm{mol}$ photons $\mathrm{m}^{2} \mathrm{~s}^{-1}$ maximum light intensity by HandyPEA-Plant Efficiency Analyser Hansatech Instruments Ltd, Norfolk, UK). The fluorescence induction curve (OJIP) were used for calculation of the Fv/Fm ratio, which shows the maximum proportion of absorbed quantum which can be used in photosystem II complex (PSII) during photosynthesis.

\section{Data analyses}

Descriptive statistical methods, including the mean, standard deviation and one-way ANOVA were used. The results were evaluated with Microsoft Office Excel and SPSS 22.0 (SPSS Inc., Chicago, IL) programmes. The significant differences between variants were determined with Tukey's test at a probability level of $5 \%$.

\section{Results}

\section{Morphological characterization of giant reed leaf varieties}

The most typical changes was the appearance of different colour longitudinal stripes on leaves (also on petiole and on leaf blade). By analysing variegated foliage, the following basic types were recorded considering the colour and position of stripes:

(I) white stripes on the middle of leaf blade - 'albovariegata' type (Figure 3a),

(II) yellowish, white and light green stripes on the middle of leaf blade - albo-aureo-variegata type,

(III) white bands on the leaf margin - 'albo-marginata' type (Figure 3b),

(IV) yellowish banded leaves - 'aureo-marginata' type (Figure 3c),

(V) yellow-light green banded leaves - 'lutescens' type (Figure 3d),

(VI) albino, yellowish-white shoots - 'alba' type.

Over the cultivation years, that type which on appeared the different colour bands on the leaf margin, their properties have been carrying same form (III, IV, V. types) despite of repeated sampling and harvesting. Varieties that have different colour stripes on the middle of leaf blade (I, II. types) have lost their properties or shoots have changed slightly by development (Figure 4). In the third and fourth cultivation year, these varieties were transformed to green type completely (Figure $4 a$ ) or white stripes (I. type) have remained largely on lower leaf surface and on petiole (Figure $4 b$ ). The yellowish-white albino (VI) type was not viable and it was dried after a few weeks of planting.

Growth habit of varieties is different (number and length of shoots, stem diameter etc.) depending on the type. White band (III) types on leaf margin and on leaf blade ('albo-marginata') differ from Arundo donax var. versicolor varieties, which described in literatures (Perdue, 1958; El-Bassam \& Dalianis, 2010). Contrary to 'versicolor' variety, in our microclimate, this 'albo-marginata' (III) type could grow only 0.7 to 1 meters average height without irrigation, have developed a lot of thinner shoots and lower leaf surface differs in colour to upper side of leaves. At the end of the growing season, these white bandings have turned beige, but the leaves dried later than 'versicolor' variety. Without irrigation with a smaller habit, this new variation could be a highly decorative new ornamental giant reed line in our climate (Figure 4a).

The growth habit of white or yellowish striped (I, II) types on the middle of leaf blade are also entirely new ornamental giant read variations. They have similar growing character to the green wild-type, the culms usually 2-3 meter high with average 15-20 pieces of shoot. However, their attractive ornamental value is primarily represented by strong white stripes primary on the lower leaf surface and petiole as well as on the internodes (Figure $4 b$ ).

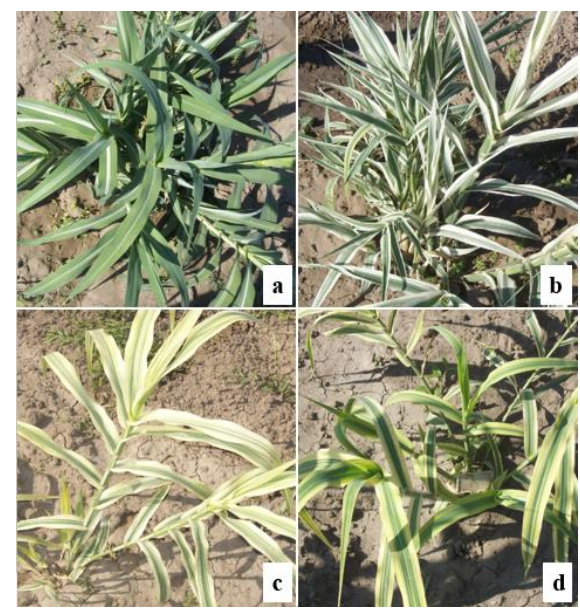

Figure 3. Leaf variants of striped giant reed originated from somatic embryogenesis (Debrecen, Hungary - July 2014)

Source: photos by Gabriella Antal

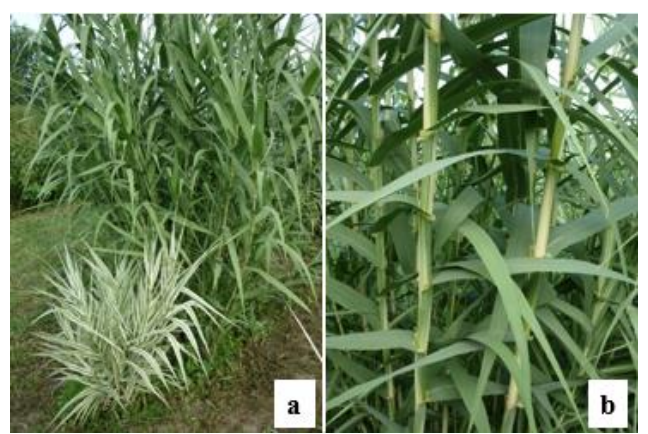

Figure 4. 3-year-old leaf variants of striped giant reed derived from somatic embryogenesis (Debrecen, Hungary - July 2015)

Source: photos by Gabriella Antal

Yellowish-light green, occasionally white banded (V) variants also have retained the characteristics of the banding on upper leaf surface. It is transition to the previously described variants (I-II), but it has developed fewer, thinner stems with longer internodes, but has not reached the average height of 2-3 meters. The leaves are close to the shoot tips are light green, which have turned yellowish by development of stem. This type is similar to the described 'Golden Chain' variety (Figure 1d). 
Characterization of photosynthetic parameters of leaf variants

The growth habit and vitality of plants are influenced by effectiveness of photosynthetic system of plants. Hence photosynthetic pigments as essential components of photosystems were measured in all variants. In content of photosynthetic pigments was significant differences $(\mathrm{p}<0.05)$ between green and 3 types of colour pattern (Figure 5). Chl $a+b$ content of green control was $49.263 \pm 3.236 \mu \mathrm{g} / \mathrm{cm}^{2}$. The total chlorophyll content of striped leaf contained less $70 \%$ $\left(14.826 \pm 0.805 \mu \mathrm{g} / \mathrm{cm}^{2}\right)$ and the light green less $87 \%$ $\left(6.726 \pm 0.689 \mu \mathrm{g} / \mathrm{cm}^{2}\right)$ than control. Total chlorophyll content of the striped leaf variety was more than twice than the light green leaves. The chlorophyll $a+b$ content was near to zero in the white area of leaves and albino shoots. Carotenoids content of light green was less with $80 \%\left(1.664 \pm 0.149 \mu \mathrm{g} / \mathrm{cm}^{2}\right)$, striped leaf was less with $70.7 \%\left(2.447 \pm 0.111 \mu \mathrm{g} / \mathrm{cm}^{2}\right)$ than green control $\left(8.350 \pm 0.0440 \mu \mathrm{g} / \mathrm{cm}^{2}\right)$. Albino/white leaf contained little amounts of carotenoids $\left(0.114 \pm 0.015 \mu \mathrm{g} / \mathrm{cm}^{2}\right)$ (Figure 5).

According to the Elhawat (2015), general chlorophyll $a / b$ ratio is adjusted 3.5-4.5, which was also measured in the green control plants (4.364). The chlorophyll $a / b$ ratio of striped leaf was similar (4.453), however the light green type there was significant difference (5.230) compared to the control. The carotenoids/chlorophyll ratio was same in case of green and striped leaf. The higher ratios of light green variety could be derived from the low content of chlorophyll a (Figure 6).

$\mathrm{Fv} / \mathrm{Fm}$ ratio as a common used photosynthetic parameter can give information about maximal quantum yield PSII. Our results show that the $\mathrm{Fv} / \mathrm{Fm}$ ratio of green, control plant is around 0.8 similar to most healthy plant species (Ashraf \& Harris, 2013), and the variants showed significantly different values. The photosynthetic activity of striped leaf variety was $93.4 \%$ (0.770), the light green leaf was $80.9 \%$ (0.667), white/albino shoot was $9.2 \%(0.076)$ compared with the green control (Figure 7). Lower value indicates that the proportion of PSII reaction centres is damaged or inactivated and the significant decrease of $\mathrm{Fv} / \mathrm{Fm}$ in white/albino shoot is related to the photosynthetic pigments' deficiency which are major components of PSII. Fv/Fm values and content of photosynthetic pigments can also contribute to the changed morphological characteristics and growth habit of plants (Papazoglou et al., 2005).

\section{Discussion}

Nowadays the giant reed is known primarily as promising bioenergy plant, at the same time it can be used for ornamental purposes in horticulture and landscape architecture. Due to its decorative appearance, colour of leaves, long growing season and low maintenance requirements, such as other popular ornamental grasses (Miscanthus, Pennisetum, Cortaderia etc.) (Meyer, 2012). The ornamental horticulture similar to fashion is always open to the plant varieties with new or unusual colours, fancy patterns or new/novel shapes. The perennial market has substantially increased in the past three decades, but this sector is also responsible for these domesticating and commercializing ornamental landscape plants do not become invasive (Anderson, 2006). Plant growth depends on photosynthesis and is influenced different biotic and abiotic stress (water or nutrient deficiency, salinity, temperature, pollutant or heavy metal, pathogens etc.). Moreover, several literature monitored morphological differences of giant reed ecotypes from different climate conditions and investigated pollutant, heavy metal and salinity tolerances of giant reed ecotypes (Alshaal et al., 2014; Elhawat et al., 2014; Kovács et al., 2015; 2016). Chlorophyll fluorescence parameters were strongly correlated with whole-plant mortality in response to environmental stresses, lower value indicates that the proportion of PSII reaction centres is damaged or inactivated (Ashraf \& Harris, 2013). According to Li et al. (2006), numerous literature observed positive correlation between chlorophyll content and photosynthetic fluorescent parameters (Fv/Fm) under stress conditions. The high photosynthetic activity of giant reed indicates a higher biomass production of this plant compared to other similar grasses with lower photosynthetic activity (Papazoglou et al., 2005).

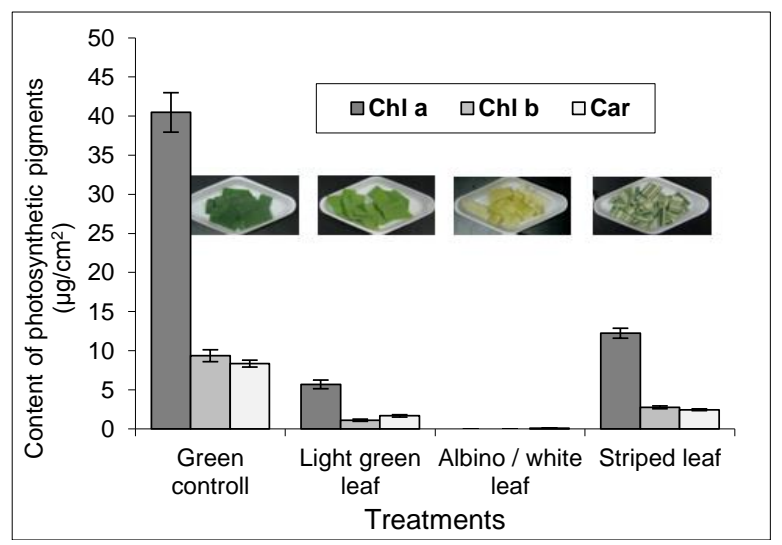

Figure 5. Photosynthetic pigments content of giant reed leaf variants Source: photos by Gabriella Antal.

It was significant differences ( $p<0.05)$ between types (Tukey test).

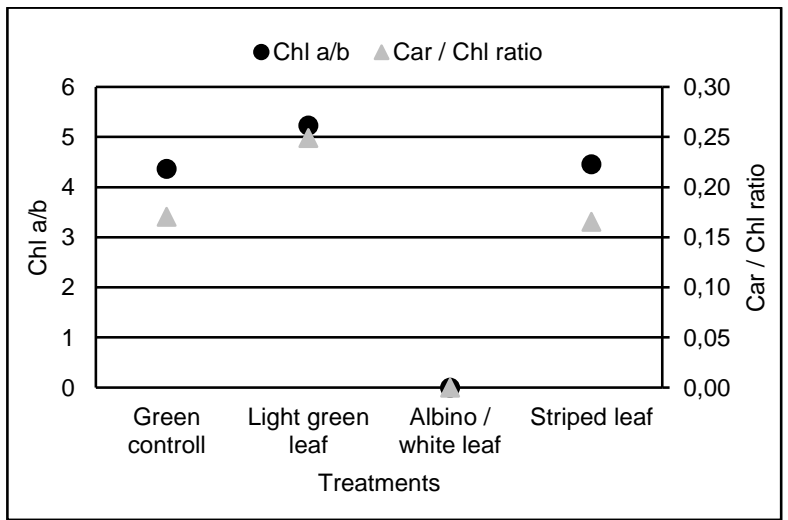

Figure 6. Chlorophyll a/b (left axis) and Carotenoids/chlorophyll ratios (right axis) in leaf variants of giant reed

It was significant differences ( $p<0.05)$ between types (Tukey test).

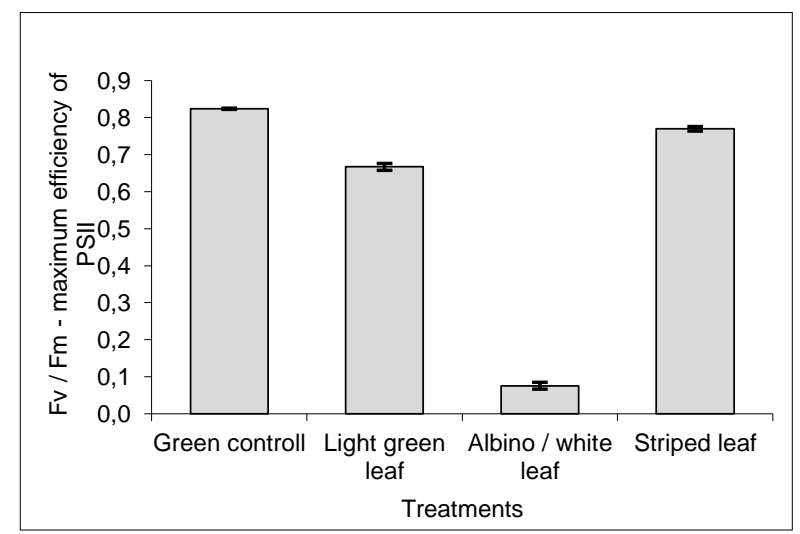

Figure 7. Photosynthetic activity (Fv/Fm ratio) of giant reed leaf variants It was significant differences ( $p<0.05)$ between types (Tukey test). 
We are carrying on the researches with analyses of morphological and photosynthetic system of giant reed variants and ecotypes. Photosynthetic activity and content of photosynthetic pigments also confirm and determine the morphological characteristics and growth habit of examining leaf variants. Along with this our present results point out that considering the colour and pattern diversity of shoot there is exploitable potential in giant reed dedicating for ornamental horticulture.

Variegations and chimerism are phenomena with both economic and scientific importance and many beautiful variegation patterns exist (such as Petunia x hybrida, Nicotinia tabacum, Miscanthus sinensis, Abutilon pictum 'Thompsonii' etc.). The terms "variegation" and "chimera" can be related and causes of these alternations clearly are complex and diverse (Marcotrigiano, 1997). Because, we have no scientific evidence of performance of investigating variants caused by variegations or chimerism, we are continuing our biological researches with molecular genetics and morphological comparisons of giant reed leaf variants. According to our best knowledge, the dwarf 'albo-marginata' (III type) growing only 0.7 to 1 meters average height without irrigation is a new and highly decorative new ornamental giant read line. In addition, the white or yellowish striped on the middle of leaf blade, named 'albo-variegata' (I and II type) are also entirely new ornamental giant read variations. They also have attractive ornamental value represented primarily by strong white stripes on the lower leaf surface and petioles as well as on the internodes. The newly obtained striped giant reed varitions with different morphological properties can be important in the breeding of new ornamental horticultural varieties (as dwarfgrowing or solitary plants or cut green plants). In addition to being utilized as dedicated bioenergy plant species with the appearance and distribution of new leaf variants, the significance of giant reed may continue to grow. For the future aspect of denomination of new variety, we continue our investigation of the most important morphological markers of leaf alternations retained after different vegetative propagation methods (rhizome-, stem cuttings, in vitro micropropagation and somatic embryogenesis).

\section{Acknowledgements}

Supported by the ÚNKP-17-3 New National Excellence Program of the Ministry of Human Capacities.

\section{References}

Alshaal, T. - Domokos-Szabolcsy, É. - Márton, L. - Czakó, M. - Kátai, J. - Balogh, P. - Elhawat, N. - El-Ramady, H. Fári, M. (2013): Phytoremediation of bauxite-derived red mud by giant reed. Environmental Chemistry Letters, 11 (3): 295 302.

Alshaal, T. - Domokos-Szabolesy, É. - Márton, L. - Czakó, M. - Kátai, J. - Balogh, P. - Elhawat, N. - El-Ramady, H. Gerôcs, A. - Fári, M. (2014): Restoring soil ecosystems and biomass production of Arundo donax L. under microbial communities-depleted soil. Bioenergy Research, 7 (1): 268278.
Anderson, N. O. (2006): Flower breeding and genetics: issues, challenges and opportunities for the $21^{\text {st }}$ century: Springer Science \& Business Media. ISBN: 1402044275. 843 p.

Angelini, L. - Ceccarini, L. - Bonari, E. (2005): Biomass yield and energy balance of giant reed (Arundo donax L.) cropped in central Italy as related to different management practices. European Journal of Agronomy, 22 (4): 375-389.

Antal, G. - Domokos-Szabolcsy, É. - Zsíros, O. - Garab, G. Koroknai, J. - Bukszár, S. - Farkas, Á. - Márton, L. - Fári, M. G. (2013): Az olasz nád (Arundo donax L.) szomatikus palánták spontán levélszín-változatai és fotoszintézisük. XIX. Növénynemesítési Tudományos Nap, Keszthely, Hungary. 73.

Antal, G. - Kurucz, E. - Fári, M. G. - Popp, J. (2014): Tissue culture and agamic propagation of winter-frost tolerant 'longicaulis' Arundo donax L. Environmental Engineering and Management Journal, 13 (11): 2709-2715.

Ashraf, M. - Harris, P. (2013): Photosynthesis under stressful environments: an overview. Photosynthetica, 51 (2): 163-190.

Bacher, W. - Mix-Wagner, G. - Sauerbeck, G. - El-Bassam, N. (2001): Giant Reed Network. Improvement, productivity, biomass quality. Final Individual Progress Report FAIR-CT96-2028. . Bundesforschungsanstalt für Landwirtschaft (FAL), Braunschweig (Germany). 1-79. http://literatur.vti.bund.de/digbib_extern/zi025259.pdf

Bell, G. P. (1997): Ecology and management of Arundo donax and approaches to riparian habitat restoration in southern California.

http://www.desertfishes.org/cuatroc/literature/pdf/Bell_1997_A rundo_ecology_management.pdf.

Big Plant Nursery (2016): Arundo donax var. versicolor. https://www.bigplantnursery.co.uk/plants/arundo-donax-varversicolor_variegated-giant-reed_691.html

Ceotto, E. - Di Candilo, M. (2010): Shoot cuttings propagation of giant reed (Arundo donax L.) in water and moist soil: The path forward? Biomass and Bioenergy, 34 (11): 1614 1623.

Christou, M. - Mardikis, M. - Kyritsis, S. - Cosentino, S. Jodice, R. - Vecchiet, M. - Gosse, G. (2001): Screening of Arundo donax L. populations in South Europe. Biomass for Energy and Industry: 2048-2051.

Corno, L. - Pilu, R. - Adani, F. (2014): Arundo donax L.: a non-food crop for bioenergy and bio-compound production. Biotechnology Advances, 32 (8): 1535-1549.

El-Bassam, N. (1996): Renewable energy: potential energy crops for Europe and the Mediterranean region. FAO, Roma (Italy), Federal Agricultural Research Centre, Braunschweig (Germany).

https://www.cabdirect.org/cabdirect/abstract/19971808654

El-Bassam, N. - Dalianis, C. (2010): Giant reed (Arundo donax L.). Bioenergy crops: a development guide and species reference, 1st ed. Earthscan publishing for a sustainable future, London: 193-199.

Elhawat, N. (2015): A study on copper-tolerance of giant reed (Arundo donax L.) ecotypes for bioenergy purposes. University of Debrecen, Debrecen, Hungary. https://dea.lib.unideb.hu/dea/bitstream/handle/2437/216088/Di ssertation.pdf? sequence $=1 \&$ is Allowed $=y$

Elhawat, N. - Alshaal, T. - Domokos-Szabolcsy, É. - ElRamady, H. - Márton, L. - Czakó, M. - Kátai, J. - Balogh, 
P. - Sztrik, A. - Molnár, M. (2014): Phytoaccumulation potentials of two biotechnologically propagated ecotypes of Arundo donax in copper-contaminated synthetic wastewater. Environmental Science and Pollution Research, 21 (12): 7773 7780 .

Ferdinands, K. - Virtue, J. - Johnson, S. B. - Setterfield, S. A. (2011): 'Bio-insecurities': managing demand for potentially invasive plants in the bioeconomy. Current Opinion in Environmental Sustainability, 3 (1): 43-49.

Future Gardens (2016): Arundo donax 'Variegata superba'. http://www.futuregardens.pl/lasecznica-trzcinowata-variegataArundo-donax.html

Gubišová, M. - Čičková, M. - Klčová, L. - Gubiš, J. (2016): In vitro tillering-An effective way to multiply high-biomass plant Arundo donax. Industrial Crops and Products, 81: 123128.

Hardion, L. (2013): Evolution et systematique du genre Arundo L. (Poaceae), et conservation d'une endemique ligure: interactions Homme/Biodiversite en Mediterranee. Systematique, phylogenie et taxonomie., Aix Marseille Universite, Francais

Hardion, L. - Verlaque, R. - Baumel, A. - Juin, M. - Vila, B. (2012): Revised systematics of Mediterranean Arundo (Poaceae) based on AFLP fingerprints and morphology. Taxon, 61 (6): 1217-1226.

Hungarian Central Statistical Office (2016): Main data of the meteorological observation stations. https://www.ksh.hu/docs/hun/xstadat/xstadat_eves/i_met002c.h tml

Invasive Plant Risk Assessment (2016): Invasive plant risk assessment: Giant reed Arundo donax. Department of Agriculture and Fisheries, Biosecurity Queensland. 18. https://www.daf.qld.gov.au/_data/assets/pdf_file/0006/59973/ IPA-Giant-Reed-Risk-Assessment.pdf

Kovács, Sz. - Kiss, P. - Lisztes-Szabó, Zs. (2016): Giant reed (Arundo donax L.) ecotypes phytolith assemblage. 10th International Meeting on Phytolith Research: 20 years of a multi-facetted research, Aix en Provence, France. Aix en Provence, France

Kovács, Sz. - Lisztes-Szabó, Zs. - Veres, Sz. - Alshaal, T. El-Ramady, H. - Fári, M. - Domokos-Szabolcsy, É. (2015): Olasznád (Arundo donax L.) ökotípusok szárazságtürésének összehasonlító vizsgálata. XXI. Növénynemesítési Tudományos Napok: MTA Agrártud. Kutatóközp., Martonvásár. 97.

Lewandowski, I. - Scurlock, J. M. - Lindvall, E. - Christou, M. (2003): The development and current status of perennial rhizomatous grasses as energy crops in the US and Europe. Biomass and Bioenergy, 25 (4): 335-361.

Li, R.-H. - Guo, P.-G. - Michael, B. - Stefania, G. Salvatore, C. (2006): Evaluation of chlorophyll content and fluorescence parameters as indicators of drought tolerance in barley. Agricultural Sciences in China, 5 (10): 751-757.

Maceda-Veiga, A. - Basas, H. - Lanzaco, G. - Sala, M. - de Sostoa, A. - Serra, A. (2016): Impacts of the invader giant reed (Arundo donax) on riparian habitats and ground arthropod communities. Biological Invasions, 18 (3): 731-749.

Mantineo, M. - D'agosta, G. - Copani, V. - Patanè, C. Cosentino, S. (2009): Biomass yield and energy balance of three perennial crops for energy use in the semi-arid Mediterranean environment. Field Crops Research, 114 (2): 204-213.

Marcotrigiano, M. (1997): Chimeras and variegation: patterns of deceit. HortScience, 32 (5): 773-784.

Mariani, C. - Cabrini, R. - Danin, A. - Piffanelli, P. Fricano, A. - Gomarasca, S. - Dicandilo, M. - Grassi, F. Soave, C. (2010): Origin, diffusion and reproduction of the giant reed (Arundo donax L.): a promising weedy energy crop. Annals of Applied Biology, 157 (2): 191-202.

Márton, L. - Czakó, M. (2002a): Selecting an explant of living tissue from the plant and cultivating the tissue on a primary medium to produce totipotent tissue. USA Patent No. US $6821782 \quad$ B2. $\quad 05.02 .2002$. https://www.google.hu/patents/US6821782?dq=US+6821782+ B2\&hl=hu\&sa=X\&ved=0ahUKEwjw4oqB0MPPAhUFjiwKH WbXAeQQ6AEIHDAA

Márton, L. - Czakó, M. (2002b): Sustained totipotent regenerable tissue culture of Arundo donax (Giant reed) and totipotent tissue and plants produced therefrom. USA Patent No. US 2002/0166149 A1. 05.02.2002. https://www.google.hu/patents/US6821782?dq=US+6821782+ B2\&hl=hu\&sa=X\&ved=0ahUKEwjw4oqB0MPPAhUFjiwKH WbXAeQQ6AEIHDAA

Márton, L. - Czakó, M. (2002c): Sustained totipotent regenerable tissue culture of Arundo donax (giant reed) and totipotent tissue and plants produced therefrom. European Patent Register, Patent No. WO 2002063023 A2. 05.02.2002. https://www.google.hu/patents/WO2002063023A2?cl=en\&dq= $\mathrm{WO}+2002063023+\mathrm{A} 2 \& \mathrm{hl}=\mathrm{hu} \& \mathrm{sa}=\mathrm{X} \& \mathrm{ved}=0 \mathrm{ahUKEwiRoJ} 2 \mathrm{j} 0$ MPPAhVJkCwKHW07Aa8Q6AEIHDAA

Márton, L. - Czakó, M. (2007a): Method for micropropagation of monocots based on sustained totipotent cell cultures. European Patent Register. https://www.google.hu/patents/EP2150100B1?cl=en\&dq=EP+ 2150100+B1\&hl=hu\&sa=X\&ved=0ahUKEwi6k93Z0MPPAh WJFiwKHXTsCr0Q6AEIHDAA

Márton, L. - Czakó, M. (2007b): Propagating Arundo species in nutrient broth and on teriary medium containing auxin and cytokinin. USA Patent No. US 7863046 B2. 07.05.2007. https://www.google.hu/patents/US7863046?dq=US+7863046+ B2\&hl=hu\&sa=X\&ved=0ahUKEwjW04fv0MPPAhVCjywKH RApCu0Q6AEIHDAA

Meyer, M. H. (2012): Ornamental grasses in the United States. Horticultural Reviews, Volume 39: 121-152.

Palm Exotics (2016): Arundo donax 'Variegata'. http://www.palms-exotics.co.uk/Arundo-donax-variegated-p585.html

Papazoglou, E. - Karantounias, G. - Vemmos, S. - Bouranis, D. (2005): Photosynthesis and growth responses of giant reed (Arundo donax L.) to the heavy metals $\mathrm{Cd}$ and $\mathrm{Ni}$. Environment International, 31 (2): 243-249.

Perdue, R. E. (1958): Arundo donax-source of musical reeds and industrial cellulose. Economic Botany, 12 (4): 368-404.

Pilu, R. - Badone, F. C. - Michela, L. (2012): Giant reed (Arundo donax L.): A weed plant or a promising energy crop? African Journal of Biotechnology, 11 (38): 9163-9174. 
Pilu, R. - Manca, A. - Landoni, M. (2013): Arundo donax as an energy crop: pros and cons of the utilization of this perennial plant. Maydica, 58 (1): 54-59.

Pompeiano, A. - Vita, F. - Miele, S. - Guglielminetti, L. (2015): Freeze tolerance and physiological changes during cold acclimation of giant reed [Arundo donax (L.)]. Grass and Forage Science, 70 (1): 168-175.

Porra, R. J. - Thompson, W. A. - Kriedemann, P. E. (1989): Determination of accurate extinction coefficients and simultaneous equations for assaying chlorophylls $a$ and $b$ extracted with four different solvents: verification of the concentration of chlorophyll standards by atomic absorption spectroscopy. Biochimica et Biophysica Acta, 975: 384-394.
Quinn, L. D. - Gordon, D. R. - Glaser, A. - Lieurance, D. Flory, S. L. (2015): Bioenergy Feedstocks at Low Risk for Invasion in the USA: a "White List" Approach. BioEnergy Research, 8 (2): 471-481.

Shatalov, A. A. - Pereira, H. (2002): Influence of stem morphology on pulp and paper properties of Arundo donax L. reed. Industrial Crops and Products, 15 (1): 77-83.

Takahashi, W. - Takamizo, T. - Kobayashi, M. - Ebina, M. (2010): Plant regeneration from calli in giant reed (Arundo donax L.). Grassland Science, 56 (4): 224-229.

Water Plants Italy (2016): Arundo donax 'Golden Chain'. http://www.waterplantsitaly.com/prodotto/Arundo-donaxgolden-chain/ 